\title{
Corynebacterium terpenotabidum sp. nov., a bacterium capable of degrading squalene
}

\author{
Mariko Takeuchi, ${ }^{1}$ Takeshi Sakane, ${ }^{1} \dagger$ Takuya Nihira, ${ }^{2}$ Yasuhiro Yamada $^{2}$ \\ and Ko Imai'¥
}

\begin{abstract}
Author for correspondence: Mariko Takeuchi. Tel: +8163006555 . Fax: +81 63006814 . e-mail: fvgg0814@mb.infoweb.ne.jp
\end{abstract}

\footnotetext{
1 Institute for Fermentation, Osaka, 17-85, Jusohonmachi 2-chome, Yodogawa-ku, Osaka 532-8686, Japan

2 Department of Fermentation Technology and Bioengineering, Osaka University, 2-1 Yamadaoka, Suita-shi, Osaka 565, Japan
}

\begin{abstract}
The taxonomic status of Arthrobacter sp. Y-11', which was described as a squalene-degrading bacterium, was investigated by chemotaxonomic and genetic methods. The strain possesses wall chemotype IV, MK-9 $\left(\mathrm{H}_{2}\right)$ as the predominant menaquinone, mycolic acids, and straight-chain, saturated and monounsaturated fatty acids, with considerable amounts of tuberculostearic acid. The DNA G+C content is $67.5 \mathrm{~mol} \%$. 165 rRNA gene sequence analysis and quantitative DNA-DNA hybridization experiments provided strong evidence that strain $\mathrm{Y}-\mathrm{11}^{\top}$ represents a new species within the genus Corynebacterium, for which the name Corynebacterium terpenotabidum sp. nov. is proposed. The type strain of $C$. terpenotabidum is strain $Y-11^{\top}$ (= IFO 14764').
\end{abstract}

Keywords: Corynebacterium terpenotabidum, squalene-degrading bacterium

\section{INTRODUCTION}

Squalene is a naturally abundant linear triterpene $\left(\mathrm{C}_{30}\right)$ and an important biosynthetic precursor of steroids and triterpenes in many living organisms. Yamada et al. (1975) reported the oxidative degradation of squalene by micro-organisms. A bacterium, strain $\mathrm{Y}-11^{\mathrm{T}}$, capable of degrading squalene was isolated from soil and tentatively named Arthrobacter sp. (Yamada et al., 1975, 1977). It was able to grow in a medium containing squalene as a sole carbon source.

Strain $\mathrm{Y}-11^{\mathrm{T}}$ is a Gram-positive, non-motile, rodshaped organism. It possesses cell wall component type IV (meso-diaminopimelic acid, arabinose and galactose) (Lechevalier \& Lechevalier, 1970), mycolic acids and menaquinone $\mathrm{MK}-9\left(\mathrm{H}_{2}\right)$, and its DNA has a $\mathrm{G}+\mathrm{C}$ content of $67.5 \mathrm{~mol} \%$. These characteristics limit strain $Y-11^{\mathrm{T}}$ to one of three genera, Corynebacterium, Gordonia or Mycobacterium.

In this paper, the characterization of strain $\mathrm{Y}-11^{\mathrm{T}}$ $\left(=\right.$ IFO $\left.14764^{\mathrm{T}}\right)$ is described. On the basis of mor-

\footnotetext{
tPresent address: Takeda Chemical Industries Ltd, 17-85, Juso-honmachi 2-chome, Yodogawa-ku, Osaka 532, Japan.

\$Present address : Research Development Corporation of Japan, Ochanomizu Meikei Bldg 6F, 2-3 Kanda Surugadai, Chiyoda-ku, Tokyo 101, Japan. Abbreviation: TBSA, tuberculostearic acid.

The DDBJ accession number for the $16 \mathrm{~S}$ rRNA sequence of strain $\mathrm{Y}-11^{\top}$ (IFO $14764^{\top}$ ) is $A B 004730$.
}

phological, physiological and chemotaxonomic characteristics, and DNA-DNA hybridization data, as well as the results of the $16 \mathrm{~S}$ rDNA sequence analysis, it is concluded that this squalene-degrading organism represents a new Corynebacterium species, for which the name Corynebacterium terpenotabidum sp. nov. is proposed.

\section{METHODS}

Bacterial strains and culture conditions. For chemical and genetic analysis, strain Y-11 ${ }^{\mathrm{T}}$ (IFO $14764^{\mathrm{T}}$ ), Corynebacterium bovis IFO $15706^{\mathrm{T}}$ (Collins \& Cummins, 1986), Corynebacterium mycetoides IFO $15289^{\mathrm{T}}$ (Collins \& Cummins, 1986), Corynebacterium variabilis IFO $15286^{\mathrm{T}}$ (Collins, 1987a), and IFO 14757 (Collins et al., 1989), Corynebacterium vitarumen IFO $12143^{\mathrm{T}}$ (Laneelle et al., 1980), and Corynebacterium xerosis IFO $15287^{\mathrm{T}}$ (Collins \& Cummins, 1986) were used. Strain IFO 14757 was a type strain of Caseobacter polymorphus (Crombach, 1978), but it has been considered to be a subjective synonym of $C$. variabilis (Collins et al., 1989). All strains were cultured at $28^{\circ} \mathrm{C}$ with aerobic shaking in a peptone-yeast extract medium supplemented with brain/heart infusion (PY-BHI medium), which contained $1 \%$ peptone, $0.2 \%$ yeast extract, $0.2 \%$ Bacto brain/heart infusion (Difco), $0 \cdot 2 \% \mathrm{NaCl}$ and $0 \cdot 2 \%$ Dglucose $(\mathrm{pH}$ 7.2). Cells used for biochemical tests were harvested by centrifugation during the stationary phase, washed with water and lyophilized. To examine the degradation of squalene (Ikeguchi et al., 1988), cells grown in $400 \mathrm{ml} \mathrm{SC}$ medium, which contained $0.3 \%(\mathrm{v} / \mathrm{v})$ salad oil, 
$0.03 \%(\mathrm{v} / \mathrm{v})$ squalene and $2 \%(\mathrm{v} / \mathrm{v})$ corn steep liquor $(\mathrm{pH}$ $7 \cdot 0$ ), at $30^{\circ} \mathrm{C}$ for $65 \mathrm{~h}$ were harvested by centrifugation and washed twice with $0.1 \mathrm{M}$ potassium phosphate buffer (pH 7.0).

Morphological, physiological and biochemical characteristics. Cell morphology was determined by phase-contrast microscopy following cell growth on PY-BHI agar. Motility was determined by the hanging drop method. Unless otherwise indicated, all tests were performed at $28^{\circ} \mathrm{C}$. Catalase activity was determined by the presence of bubbles in a $3 \%$ hydrogen peroxide solution. Oxidase activity was determined by the oxidation of $1 \%$ tetramethyl-p-phenylenediamine on filter paper. Organic acid assimilation was studied in a medium containing $\left(1^{-1}\right) 0.5 \%$ organic acid (sodium salt), $0.02 \%$ D-glucose, $0.01 \%$ yeast extract, $0.01 \%$ Trypticase (BBL), $0 \cdot 1 \% \mathrm{~K}_{2} \mathrm{HPO}_{4}, 0.5 \% \mathrm{NaCl}, 2 \%$ agar and $12 \mathrm{mg}$ phenol red ( $\mathrm{pH} \mathrm{7.0)}$. Acid production from carbohydrates was studied in a medium containing $1 \%$ peptone, $0.5 \% \mathrm{NaCl}, 0.003 \%$ bromocresol purple and $0.5 \%$ carbohydrate ( $\mathrm{pH} 7 \cdot 2)$ (Cowan, 1974). Nitrate reduction and hydrolysis of casein, cellulose, aesculin, gelatin, starch, tyrosine and Tween 80 were tested using methods described by Cowan (1974).

Cell chemistry. Cell walls were prepared from about $500 \mathrm{mg}$ (dry weight) bacterial cells as described by Schleifer \& Kandler (1972). Amino acids in the acid hydrolysate of the cell walls were identified by two-dimensional chromatography on cellulose TLC plates (Tokyo Kasei) by the method of Harper \& Davis (1979) and by HPLC according to the manufacturer's instructions. Cell wall sugars were analysed as described by Mikami \& Ishida (1983). The glycolyl test was performed by the method of Uchida \& Aida (1977). Fatty acids were extracted from dried cells, purified (Minnikin et al., 1979; Suzuki \& Komagata, 1983), and analysed by GLC-MS with a GCMS-QP5000 spectrometer (Shimadzu) combined with a CLASS-5000 MS Workstation computer system. GLC analyses were carried out using a GC-17A gas chromatograph (Shimadzu). A BPX70 capillary column (SGE) containing $70 \%$ cyanopropyl equivalent modified siloxane $(50 \mathrm{~m} \times 0.25 \mathrm{~mm})$ was used at $80^{\circ} \mathrm{C}$ for $2 \mathrm{~min}, 80-150^{\circ} \mathrm{C}$ at $15^{\circ} \mathrm{C} \min ^{-1}, 150-250^{\circ} \mathrm{C}$ at $8^{\circ} \mathrm{C}$ $\mathrm{min}^{-1}$, and then $250^{\circ} \mathrm{C}$ for $5 \mathrm{~min}$, with helium as carrier gas at a flow rate of $1.4 \mathrm{ml} \mathrm{min}{ }^{-1}$. Mycolic acids were analysed by the method of Minnikin et al. (1975). Menaquinones were extracted from dry cells $(200 \mathrm{mg})$ with chloroform-methanol $(2: 1, v / v)$, purified by TLC (Kieselgel $60 \mathrm{~F}_{254}$ plates; Merck) using hexane-diethyl ether $(85: 15, \mathrm{v} / \mathrm{v})$ as a solvent, extracted with acetone, dried under a nitrogen stream, then analysed by HPLC with a Shimadzu model LC-5A instrument equipped with a Zorbax octyldecyl silane column $(150 \times 4.6 \mathrm{~mm})$.

Degradation of squalene. Cells grown in $400 \mathrm{ml} \mathrm{SC}$ medium at $30{ }^{\circ} \mathrm{C}$ for $65 \mathrm{~h}$ were harvested by centrifugation at $6000 \mathrm{~g}$ for $15 \mathrm{~min}$, washed twice with $0 \cdot 1 \mathrm{M}$ potassium phosphate

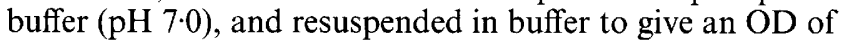
10 in a $1 \mathrm{~cm}$ light path at $600 \mathrm{~nm}$. The cell suspension $(1 \mathrm{ml})$ and $0.2 \mathrm{ml}$ of squalene were mixed in a test tube and incubated on a reciprocating shaker $\left(150\right.$ strokes $\left.\mathrm{min}^{-1}\right)$ at $35^{\circ} \mathrm{C}$ for $3 \mathrm{~h}$. The reaction products were analysed by GLC by the method of Ikeguchi et al. (1988).

Genetic properties. DNA was obtained by the method of Saito \& Miura (1963). The $\mathrm{G}+\mathrm{C}$ content of the DNA was determined by HPLC of P1 nuclease hydrolysates of genomic DNA (Mesbah et al., 1989; Tamaoka \& Komagata, 1984). DNA-DNA hybridization was carried out fluoro- metrically in microdilution wells using biotinylated DNA (Ezaki et al., 1989).

165 rDNA sequence determination and phylogenetic analysis. 16S rRNA-specific DNA was amplified by PCR and sequenced directly (Hiraishi, 1992; Hiraishi et al., 1994) with a Thermo Sequenase fluorescent-labelled primer cycle sequencing kit with 7-deaza-dGTP (Amersham Life Science) and a Pharmacia ALF DNA sequencer according to the manufacturers' protocols. Nucleotide substitution rates ( $K_{\text {nuc }}$ values) were calculated (Kimura, 1980), and the phylogenetic tree was constructed by the neighbour-joining method (Saitou \& Nei, 1987). The topology of the phylogenetic tree was evaluated by the bootstrap resampling method of Felsenstein (1985) with 1000 replicates.

Nucleotide sequence accession numbers. The DDBJ accession number of the nucleotide sequence data of strain $\mathrm{Y}$ $11^{\mathrm{T}}$ (IFO 14764 ${ }^{\mathrm{T}}$ ) is AB004730. The sequence was aligned with published sequences from DDBJ, GenBank and EMBL.

\section{RESULTS}

\section{Morphological and physiological characteristics}

Strain Y-1 $1^{\mathrm{T}}$ was a Gram-positive, non-acid-fast, nonmotile rod. Colonies on PY-BHI agar were circular, had a rough surface and were greyish-white. No aerial mycelia and no diffusible pigments were produced. In young cultures, cells were rod-shaped, $(0.5-0.7$ by $1 \cdot 0-1 \cdot 5 \mu \mathrm{m})$ and some were arranged at an angle in a V formation. In older cultures, rods became shorter $(0.5-0.7$ by $0.6-1.0 \mu \mathrm{m})$. The strain grew under aerobic, but not anaerobic conditions. Thiamin and biotin were required for growth. Growth was observed in PY-BHI broth containing $8 \% \mathrm{NaCl}$, but not in $10 \% \mathrm{NaCl}$. Strain $\mathrm{Y}-11^{\mathrm{T}}$ utilized fructose, galactose, lactate, mannose and ethanol, but did not produce acid from these carbohydrates. The other phenotypic characteristics of strain $\mathrm{Y}-11^{\mathrm{T}}$ are summarized in Table 1.

\section{Chemotaxonomic characteristics}

The purified cell wall of strain $\mathrm{Y}-11^{\mathrm{T}}$ contained alanine, glutamic acid and meso-diaminopimelic acid in a molar ratio of $2 \cdot 12: 1 \cdot 00: 0 \cdot 97$. The main components of the cell wall sugars were arabinose, galactose and mannose in a molar ratio of $2 \cdot 47: 1 \cdot 71: 1 \cdot 00$. The glycan moiety of the cell wall contained acetyl residues. The major fatty acids of strain $\mathrm{Y}-11^{\mathrm{T}}$ were $\mathrm{C}_{16: 0}(28 \%$ total cellular fatty acids), $\mathrm{C}_{18: 0}(7 \%), \mathrm{C}_{18: 1}(34 \%), \mathrm{C}_{16: 1}$ $(5 \%), \mathrm{C}_{17: 1}(5 \%)$, and 10-Me- $\mathrm{C}_{18: 0}$ [tuberculostearic acid (TBSA)] $(21 \%)$. The DNA G $+\mathrm{C}$ content of strain $\mathrm{Y}-11^{\mathrm{T}}$ was $67.5 \mathrm{~mol} \%$. The whole-cell methanolysate of strain $\mathrm{Y}-11^{\mathrm{T}}$ contained mycolic esters.

\section{Degradation of squalene}

Strain $\mathrm{Y}-11^{\mathrm{T}}$ was able to degrade linear terpenes including squalene (Willet et al., 1967) and oxidatively cleave the central part of the squalene molecule (Ikeguchi et al., 1988); this regioselective cleavage 
Table 1. Phenotypic characteristics of $C$. terpenotabidum

Assimilation of fructose, glucose, mannose, lactate and ethanol is positive. Assimilation of arginine, aspartate, histidine, methylamine, ethylamine, methanol, galactose, lactose, maltose, sucrose, glycerol, sorbitol, mannitol, inositol, citrate, succinate, malonate, pimelate, $m$ hydroxybenzoate and $p$-hydroxybenzoate is negative.

\begin{tabular}{|lc|}
\hline Phenotypic characteristic & Result \\
\hline Catalase & + \\
Oxidase & - \\
OF test & Oxidative \\
Hydrolysis of: & \\
Tween 80 & + \\
Starch & - \\
Gelatin & - \\
Cellulose & - \\
Aesculin & - \\
Tyrosine & - \\
Acid-fast & - \\
Urease formation & + \\
Lysine decarboxylase & - \\
Ornithine decarboxylase & - \\
Nitrate reduction & - \\
Voges-Proskaur test & + \\
Methyl red test & - \\
Arginine dihydrolase & - \\
Growth in: & - \\
$0 \% \mathrm{NaCl}$ & + \\
$8.0 \% \mathrm{NaCl}$ & - \\
$10 \% 0 \% \mathrm{NaCl}$ & \\
\hline
\end{tabular}

forms two molecules of trans-geranylacetone. In contrast, C. mycetoides IFO $15289^{\mathrm{T}}, C$. variabilis IFO $15286^{\mathrm{T}}$ and $14757, C$. vitarumen IFO $12143^{\mathrm{T}}$, and $C$. xerosis IFO $15287^{\mathrm{T}}$ did not degrade squalene (data not shown).

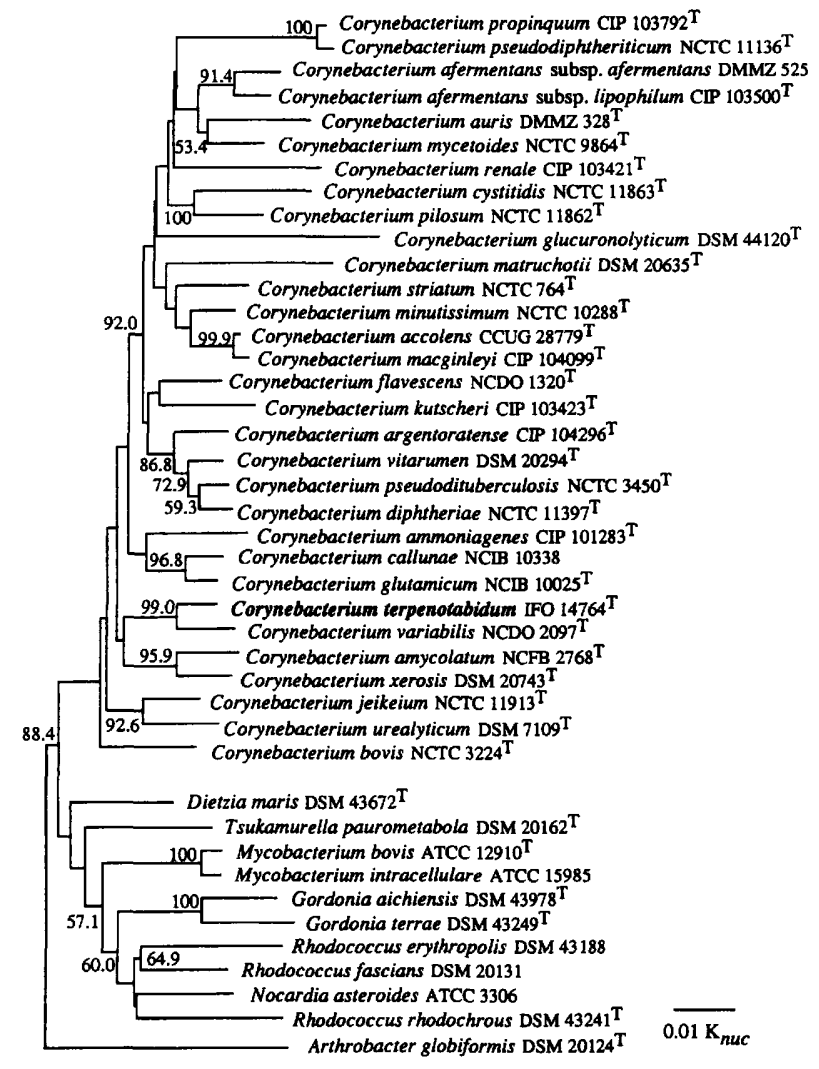

Fig. 1. Unrooted phylogenetic tree displaying the relationships of C. terpenotabidum IFO $14764^{\top}$ to reference organisms. The numbers on the branch points of the tree indicate bootstrap values (percentage) derived from 1000 samples (Felsenstein, 1985). Bar, $0.01 K_{\text {nuc }}$ unit.

\section{DNA-DNA relatedness}

The levels of DNA-DNA relatedness among strain Y$11^{\mathrm{T}}$ and $C$. bovis IFO $15706^{\mathrm{T}}, C$. mycetoides IFO $15289^{\mathrm{T}}, C$. variabilis IFO $15286^{\mathrm{T}}$ and $14757, C$. vitarumen IFO $12143^{\mathrm{T}}$, and C. xerosis IFO $15287^{\mathrm{T}}$ was $5-30 \%$ (Table 2).

Table 2. DNA base compositions and levels of DNA relatedness between $C$. terpenotabidum and related Corynebacterium species

\begin{tabular}{|c|c|c|c|c|c|c|c|}
\hline \multirow[t]{2}{*}{ Species } & \multirow{2}{*}{$\begin{array}{c}\text { Strain } \\
\text { (IFO no.) }\end{array}$} & \multirow{2}{*}{$\underset{(\mathrm{mol} \%)}{\mathbf{G}+\mathbf{C} \text { content }}$} & \multicolumn{5}{|c|}{ DNA-DNA reassociation (\%) with: } \\
\hline & & & $14764^{T}$ & $15289^{\mathrm{T}}$ & $15286^{\mathrm{T}}$ & $12143^{\mathrm{T}}$ & $15287^{\mathrm{T}}$ \\
\hline C. terpenotabidum & $14764^{\mathrm{T}}$ & $67 \cdot 5$ & 100 & 9 & 30 & 8 & 8 \\
\hline C. bovis & $15706^{\mathrm{T}}$ & $68 \cdot 8$ & 7 & ND & ND & ND & ND \\
\hline C. mycetoides & $15289^{\mathrm{T}}$ & $63 \cdot 6$ & 11 & 100 & 5 & 10 & 13 \\
\hline C. variabilis & $15286^{\mathrm{T}}$ & $67 \cdot 0$ & 19 & 9 & 100 & 8 & 10 \\
\hline C. variabilis & 14747 & 66.8 & 13 & 7 & 84 & 8 & 9 \\
\hline C. vitarumen & $12143^{\mathrm{T}}$ & 63.9 & 12 & 11 & 10 & 100 & 12 \\
\hline C. xerosis & $15287^{\mathrm{T}}$ & 67.3 & 10 & 8 & 5 & 12 & 100 \\
\hline
\end{tabular}

ND, Not determined. 
Table 3. Levels of $16 \mathrm{~S}$ rRNA sequence similarity among $C$. terpenotabidum sp. nov., other Corynebacterium species and related organisms

\begin{tabular}{|c|c|c|c|}
\hline Species & Strain* & EMBL no. & 16S rRNA similarity $(\%)$ \\
\hline Corynebacterium accolens & CCUG 28779 & $\mathrm{X} 80500$ & $96 \cdot 2$ \\
\hline Corynebacterium afermentans subsp. afermentans & DMMZ 525 & X81874 & $95 \cdot 4$ \\
\hline Corynebacterium afermentans subsp. lipophilum & CIP $103500^{\mathrm{T}}$ & $\mathrm{X} 82055$ & $95 \cdot 8$ \\
\hline Corynebacterium ammoniagenes & CIP $101283^{\mathrm{T}}$ & $\mathrm{X} 84440$ & $96 \cdot 0$ \\
\hline Corynebacterium amycolatum & NCFB $2768^{\mathrm{T}}$ & X84244 & $96 \cdot 1$ \\
\hline Corynebacterium argentoratense & CIP $104296^{T}$ & $\mathrm{X} 83955$ & $96 \cdot 9$ \\
\hline Corynebacterium auris & DMMZ $328^{\mathrm{T}}$ & X82493 & $95 \cdot 0$ \\
\hline Corynebacterium bovis & NCTC $3224^{T}$ & X84444 & $97 \cdot 2$ \\
\hline Corynebacterium callunae & NCIB 10338 & $\mathrm{X} 84251$ & $97 \cdot 2$ \\
\hline Corynebacterium cystitidis & NCTC $11863^{\mathrm{T}}$ & X84252 & $94 \cdot 7$ \\
\hline Corynebacterium diphtheriae & NCTC $11397^{\mathrm{T}}$ & X84248 & 96.8 \\
\hline Corynebacterium flavescens & NCDO $1320^{T}$ & X84441 & $97 \cdot 4$ \\
\hline Corynebacterium glucuronolyticum & DSM $44120^{\mathrm{T}}$ & X86688 & $93 \cdot 7$ \\
\hline Corynebacterium glutamicum & NCIB $10025^{\mathrm{T}}$ & X84257 & $97 \cdot 0$ \\
\hline Corynebacterium jeikeium & NCTC $11913^{\mathrm{T}}$ & $\mathrm{X} 84250$ & $96 \cdot 9$ \\
\hline Corynebacterium kutscheri & CIP $103423^{\mathrm{T}}$ & X81871 & $95 \cdot 7$ \\
\hline Corynebacterium macginleyi & CIP $104099^{\mathrm{T}}$ & X80499 & $95 \cdot 9$ \\
\hline Corynebacterium matruchotii & DSM $20635^{\mathrm{T}}$ & X84443 & $94 \cdot 6$ \\
\hline Corynebacterium minutissimum & NCTC $10288^{T}$ & X84678 & $96 \cdot 4$ \\
\hline Corynebacterium mycetoides & NCTC $9864^{\mathrm{T}}$ & X84241 & $95 \cdot 5$ \\
\hline Corynebacterium pilosum & NCTC $11862^{\mathrm{T}}$ & X84246 & $95 \cdot 4$ \\
\hline Corynebacterium propinquum & CIP $103792^{\mathrm{T}}$ & X84438 & $95 \cdot 1$ \\
\hline Corynebacterium pseudodiphthereticum & NCTC $11136^{\mathrm{T}}$ & $\mathrm{X} 84258$ & $95 \cdot 0$ \\
\hline Corynebacterium pseudotuberculosis & NCTC $3450^{\mathrm{T}}$ & X84255 & $96 \cdot 6$ \\
\hline Corynebacterium renale & CIP $103421^{\mathrm{T}}$ & X84249 & $95 \cdot 0$ \\
\hline Corynebacterium striatum & NCTC $764^{T}$ & X84442 & $96 \cdot 7$ \\
\hline Corynebacterium urealyticum & DSM $7109^{\mathrm{T}}$ & X84439 & $96 \cdot 7$ \\
\hline Corynebacterium variabilis & NCDO $2097^{T}$ & X53185 & $98 \cdot 3$ \\
\hline Corynebacterium vitarumen & DSM $20294^{\mathrm{T}}$ & $X 84680$ & $97 \cdot 4$ \\
\hline Corynebacterium xerosis & DSM $20743^{T}$ & X84446 & $97 \cdot 0$ \\
\hline Arthrobacter globiformis & DSM $20124^{\mathrm{T}}$ & M23411 & $93 \cdot 2$ \\
\hline Dietzia maris & DSM $43672^{\mathrm{T}}$ & X79286 & $95 \cdot 5$ \\
\hline Gordonia aichiensis & DSM $43978^{\mathrm{T}}$ & X80633 & 93.9 \\
\hline Gordonia terrae & DSM $43249^{\mathrm{T}}$ & X79286 & $93 \cdot 2$ \\
\hline Mycobacterium bovis & ATCC $12910^{\mathrm{T}}$ & X55589 & $94 \cdot 6$ \\
\hline Mycobacterium intracellulare & ATCC 15985 & X52927 & $94 \cdot 6$ \\
\hline Nocardia asteroides & ATCC 3306 & X57949 & 93.6 \\
\hline Rhodococcus erythropolis & DSM 43188 & X53203 & $94 \cdot 5$ \\
\hline Rhodococcus fascians & DSM 20131 & X53204 & $93 \cdot 4$ \\
\hline Rhodococcus rhodochrous & DSM $43241^{\mathrm{T}}$ & X82936 & $95 \cdot 1$ \\
\hline Tsukamurella paurometabola & DSM $20162^{\mathrm{T}}$ & X53206 & $93 \cdot 2$ \\
\hline
\end{tabular}

* ATCC, American Type Culture Collection, Manassas, VA, USA; CCUG, Culture Collection of the University of Göteborg, Göteborg, Sweden; CIP, Collection of Institute Pasteur, Paris, France; DMMZ, Culture Collection of the Department of Medical Microbiology, University of Zürich, Zürich, Switzerland; DSM, German Collection of Microorganisms, Braunschweig, Germany; NCDO, National Collection of Dairy Organisms, Reading, UK; NCFB, National Collection of Food Bacteria, Reading, UK; NCIB, National Collection of Industrial and Marine Bacteria, Aberdeen, UK; NCTC, National Collection of Type Cultures, London, UK. $\mathbf{T}=$ Type strain.

\section{Phylogenetic analysis}

A total of 1499 nucleotides of the 16S rDNA of strain $\mathrm{Y}-11^{\mathrm{T}}$ were sequenced, and the primary structure was aligned with sequences of 42 reference coryneform bacteria. Because only partial sequences were available for some of the reference strains, sequence similarity calculations were based on 957 nucleotides.

Fig. 1 shows an unrooted tree constructed from a matrix of sequence similarities, which clearly demonstrates that strain $\mathrm{Y}-11^{\mathrm{T}}$ is a member of the genus 
Corynebacterium. Both sequence similarity values and the treeing analysis revealed that the phylogenetically closest corynebacterium to strain $\mathrm{Y}-11^{\mathrm{T}}$ is $C$. variabilis; the $16 \mathrm{~S}$ rDNA sequence similarity was $98.3 \%$ (Table 3).

\section{DISCUSSION}

From the results of this work, it is evident that strain $\mathrm{Y}-11^{\mathrm{T}}$, which was described as a squalene-degrading bacterium, is a new Corynebacterium species.

In the genus Corynebacterium, 41 validated species have been previously determined. Comparative analyses of 16S rDNA sequences revealed that the species of the genus Corynebacterium form a monophyletic association within the taxa containing chemotype IV and mycolic acid, though there is heterogeneity within this genus (Funke et al., 1997; Pascual et al., 1995; Ruimy et al., 1995). For example, both aerobic and facultatively anaerobic species are included in this genus; some species lack mycolic acid (Collins et al., 1988); some species contain TBSA (Bendinger et al., 1992; Collins et al., 1982; Suzuki \& Komagata, 1983) and so on.

Among the 41 validated species, seven Corynebacterium species have been known to contain TBSA: Corynebacterium ammoniagenes (Collins, 1987b); $C$. bovis (Collins et al., 1988); Corynebacterium cystitidis, Corynebacterium minutissimum and Corynebacterium pilosum (Herrera-Alcaraz et al., 1990); Corynebacterium urealyticum (Pitcher et al., 1992); and $C$. variabilis (Collins, 1987a; Collins et al., 1982). In this study, it was clarified that strain $\mathrm{Y}-11^{\mathrm{T}}$ is a TBSAcontaining corynebacterium.

On the other hand, the generally accepted range of DNA G + C contents for Corynebacterium species had been reported to be $51-63 \mathrm{~mol} \%$ (Collins \& Cummins, 1986). However, $\mathrm{G}+\mathrm{C}$ contents higher than $63 \mathrm{~mol} \%$ have been reported in several Corynebacterium species: Corynebacterium afermentans $(66-68 \mathrm{~mol} \%)$, C. afermentans subsp. afermentans $(66 \mathrm{~mol} \%), C$. afermentans subsp. lipophilum (68 mol\%) (Riegel et al., 1993a, b), Corynebacterium auris (68-74 mol\%) (Funke et al., 1995), C. bovis (68-74 mol \%) (Riegel et al., 1993b), C. mycetoides (68 mol \%) (Pitcher, 1983; Riegel et al., 1993b), C. variabilis (65 mol \%) (Collins, $1987 \mathrm{a}$; Collins et al., 1989), C. vitarumen $(64.8 \mathrm{~mol} \%)$ (Collins \& Cummins, 1986) and C. xerosis $(71 \mathrm{~mol} \%)$ (Riegel et al., 1993b). Table 4 lists some of the characteristics that distinguish strain $\mathrm{Y}-11^{\mathrm{T}}$ from these high $\mathrm{G}+\mathrm{C}$ content corynebacteria. Strain $\mathrm{Y}-11^{\mathrm{T}}$ can be distinguished from C. bovis and C. variabilis, which contain TBSA, in that $\mathrm{Y}-11^{\mathrm{T}}$ possesses urease activity, does not reduce nitrate to nitrite and produces acid from mannose. Squalene-degrading ability was not found in $C$. bovis IFO $15706^{\mathrm{T}}$, C. mycetoides IFO $15289^{\mathrm{T}}$, C. variabilis IFO $15286^{\mathrm{T}}, C$. vitarumen $\mathrm{IFO}$ $12143^{\mathrm{T}}$ and $C$. xerosis IFO $15287^{\mathrm{T}}$ (data not shown), and these phenotypic data clearly support the idea that strain $\mathrm{Y}-11^{\mathrm{T}}$ represents a new taxon.

The levels of DNA-DNA relatedness of strain $\mathrm{Y}-11^{\mathrm{T}}$ with $C$. bovis IFO $15706^{\mathrm{T}}, C$. mycetoides IFO $15289^{\mathrm{T}}$, C. variabilis IFO $15286^{\mathrm{T}}$ and $14757, C$. vitarumen IFO $12143^{\mathrm{T}}$, and $C$. xerosis IFO $15287^{\mathrm{T}}$ were less than $30 \%$.

Comparison of the 16S rDNA sequence of strain Y$11^{\mathrm{T}}$ with those of the 31 species of the genus Corynebacterium revealed that the highest level of $16 \mathrm{~S}$ rDNA sequence similarity was $98.3 \%$ with $C$. variabilis.

On the basis of morphological, physiological and chemotaxonomic characteristics, together with DNA-DNA hybridization data and 16S rDNA se-

Table 4. Characteristics useful for differentiating $C$. terpenotabidum from other high $\mathrm{G}+\mathrm{C}$ content corynebacteria

Data from this study and previous studies (Collins, 1987a; Collins \& Cummins, 1986; Collins et al., 1989; Funke et al., 1995; Pitcher et al., 1992; Riegel et al., 1993b). +, $90 \%$ or more of strains are positive;,$- 90 \%$ or more of strains are negative; ND, not determined.

\begin{tabular}{|c|c|c|c|c|c|c|c|}
\hline \multirow[t]{2}{*}{ Species } & \multirow{2}{*}{$\begin{array}{l}\text { Nitrate } \\
\text { reduction }\end{array}$} & \multirow{2}{*}{$\begin{array}{l}\text { Urease } \\
\text { activity }\end{array}$} & \multirow{2}{*}{$\begin{array}{l}\text { Hydrolysis } \\
\text { of aesculin }\end{array}$} & \multicolumn{3}{|c|}{ Acid from :* } & \multirow{2}{*}{$\begin{array}{c}\text { Presence of } \\
\text { TBSA } \dagger\end{array}$} \\
\hline & & & & Fruc & Glc & Man & \\
\hline C. terpenotabidum & - & + & - & - & - & + & + \\
\hline C. afermentans subsp. afermentans & - & - & - & ND & - & - & - \\
\hline C. afermentans subsp. lipophilum & - & - & - & ND & - & - & - \\
\hline C. mycetoides & - & - & - & ND & + & - & - \\
\hline C. variabilis & + & + & - & - & - & - & + \\
\hline C. vitarumen & + & + & + & + & + & + & - \\
\hline C. xerosis & + & - & - & + & + & + & - \\
\hline
\end{tabular}

* Fruc, fructose; Glc, glucose; Man, mannose.

$\uparrow$ TBSA, tuberculostearic acid. 
quence comparison data, it is concluded that this squalene-degrading organism, strain $\mathrm{Y}-11^{\mathrm{T}}$, should be a new species of the genus Corynebacterium, Corynebacterium terpenotabidum. The type strain is strain $\mathrm{Y}-11^{\mathrm{T}}$ (= IFO $\left.14764^{\mathrm{T}}\right)$.

\section{Description of Corynebacterium terpenotabidum sp. nov.}

Corynebacterium terpenotabidum (terpeno.ta'bi.dum. L. fem. n. terpeno terpene; L. adj. tabidum dissolving; M.L. fem. adj. terpenotabidum terpene-dissolving).

Cells are Gram-positive, irregular rods $0.5-0.7 \mu \mathrm{m}$ by $1 \cdot 0-1.5 \mu \mathrm{m}$ long in young cultures; some cells are arranged at an angle in a V formation. In old cultures, cells are $0.5-0.7 \mu \mathrm{m}$ by $0.6-1.0 \mu \mathrm{m}$. Rods are Grampositive, non-acid-fast, non-sporulating and non-motile. No mycelium is produced. Colonies on PY-BHI agar are circular, have a rough surface and are greyishwhite. Methyl red test negative. Nitrate is not reduced to nitrite. Growth occurs under aerobic, but not anaerobic conditions. Hugh-Leifson's test in glucose oxidation-fermentation (OF) medium is oxidative. Voges-Proskauer test positive. Catalase and urease are produced, but oxidase, arginine dihydrolase, lysine decarboxylase and ornithine decarboxylase are not. Tween 80 is hydrolysed, but starch, gelatin, casein, cellulose, aesculin and tyrosine are not. Fructose, glucose, mannose, lactate and ethanol are utilized as carbon sources, but galactose, lactose, maltose, sucrose, glycerol, sorbitol, mannitol, inositol, citrate, succinate, malonate, pimelate, $m$-hydroxybenzoate, $p$-hydroxybenzoate, arginine, aspartate, histidine, methylamine, ethylamine and methanol are not. Thiamin and biotin are required for growth. Growth is observed in PY-BHI broth containing $8 \% \mathrm{NaCl}$, but not in $10 \% \mathrm{NaCl}$. Cell wall peptidoglycan contains meso-diaminopimelic acid as the only diamino acid, arabinose, galactose and mannose, as major cell wall sugars. The muramic acids of peptidoglycan occur in the $\mathrm{N}$-acetyl form. The predominant isoprenoid quinone is menaquinone MK-9 $\left(\mathrm{H}_{2}\right)$. Mycolic acids are present. The main straight-chain saturated acids are palmitic acids and the unsaturated fatty acid are oleic acids. High levels of TBSA are present. The $\mathrm{G}+\mathrm{C}$ content of the DNA is $67.5 \mathrm{~mol} \%$. The type strain, strain Y $-11^{\mathrm{T}}$ (=IFO $14764^{\mathrm{T}}$ ), was isolated from soil.

\section{REFERENCES}

Bendinger, B., Kroppenstedt, R. M., Klatte, S. \& Altendorf, K. (1992). Chemotaxonomic differentiation of coryneform bacteria isolated from biofilters. Int $J$ Syst Bacteriol 42, 474486.

Collins, M. D. (1987a). Transfer of Arthrobacter variabilis (Müller) to the genus Corynebacterium, as Corynebacterium variabilis comb. nov. Int J Syst Bacteriol 37, 287-288.

Collins, M. D. (1987b). Transfer of Brevibacterium ammoniagenes (Cooke and Keith) to the genus Corynebacterium as Corynebacterium ammoniagenes comb. nov. Int J Syst Bacteriol 37, 442-443.

Collins, M. D. \& Cummins, C. S. (1986). Genus Corynebacterium.
In Bergey's Manual of Systematic Bacteriology, vol. 2, pp. 1266-1283. Edited by P. H. A. Sneath, N. S. Mair, M. E. Sharpe \& J. G. Holt. Baltimore: Williams \& Wilkins.

Collins, M. D., Goodfellow, M. \& Minnikin, D. E. (1982). Fatty acid composition of some mycolic acid-containing coryneform bacteria. J Gen Microbiol 128, 2503-2509.

Collins, M. D., Burton, R. A. \& Jones, D. (1988). Corynebacterium amycolatum sp. nov., a new mycolic acid-less Corynebacterium species from human skin. FEMS Microbiol Lett 49, 349-352.

Collins, M. D., Shimada, J. \& Stackebrandt, E. (1989). Phylogenetic evidence for the transfer of Caseobacter polymorphys (Crombach) to the genus Corynebacterium. Int $J$ Syst Bacteriol 39, 7-9.

Cowan, S. T. (1974). Cowan and Steel's Manual for the Identification of Medical Bacteria. London: Cambridge University Press.

Crombach, W. H. J. (1978). Caseobacter polymorphus gen. nov., sp. nov., a coryneform bacterium from cheese. Int $J$ Syst Bacteriol 28, 354-366.

Ezaki, T., Hashimoto, Y. \& Yabuuchi, E. (1989). Fluorometric deoxyribonucleic acid-deoxyribonucleic acid hybridization in microdilution wells as an alternative to membrane filter hybridization in which radioisotopes are used to determine genetic relatedness among bacterial strain. Int $J$ Syst Bacteriol 39, 224-229.

Felsenstein, J. (1985). Confidence limits on phylogenies: an approach using the bootstrap. Evolution 39, 783-791.

Funke, G., Lawson, P. A. \& Collins, M. D. (1995). Heterogeneity within human-derived Centers for Disease Control and Prevention (CDC) coryneform group ANF-1-like bacteria and description of Corynebacterium auris sp. nov. Int $J$ Syst Bacteriol 45, 735-739.

Funke, G., Romos, C. P. \& Collins, M. (1997). Corynebacterium coyleae sp. nov., isolated from human clinical specimens. Int $J$ Syst Bacteriol 47, 92-96.

Harper, J. J. \& Davis, G. H. G. (1979). Two-dimensional thin-layer chromatography for amino acid analysis of bacterial cell walls. Int J Syst Bacteriol 29, 56-58.

Herrera-Alcaraz, E. A., Valero-Guillén, P. L., Martin-Luengo, F. \& Soriano, F. (1990). Taxonomic implications of the chemical analysis of the D2 group of corynebacteria. FEMS Microbiol Lett 72, 341-344.

Hiraishi, A. (1992). Direct automated sequencing of 16S rRNA amplified by polymerase chain reaction from bacterial culture without DNA purification. Lett Appl Microbiol 15, 210-213.

Hiraishi, A., Shin, Y. K., Ueda, Y. \& Sugiyama, J. (1994). Automated sequencing of PCR-amplified 16S rRNA on 'Hydrolink' gels. J Microbiol Methods 19, 145-154.

Ikeguchi, N., Nihira, T., Kishimoto, A. \& Yamada, T. (1988). Oxidative pathway form squalene to geranylacetone in Arthrobacter sp. strain Y-11. Appl Environ Microbiol 54, 381-385.

Kimura, M. (1980). A simple method for estimating evolutionary rates of base substitutions through comparative studies of nucleotide sequences. $J \mathrm{Mol}$ Evol 16, 111-120.

Laneelle, M. A., Asselineau, J., Welby, M., Norgard, M. V., Imaeda, T., Pollice, M. C. \& Barksdale, L. (1980). Biological and chemical bases for the reclassification of Brevibacterium vitarumen (Bechdel et al.) Breed (Approved Lists, 1980) as Corynebacterium vitarumen (Bechdel et al.) comb. nov and Brevibacterium liquefaciens Okabayashi and Masuo (Approved Lists, 1980) as Corynebacterium liquefaciens (Okabayashi and Masuo) comb. nov. Int J Syst Bacteriol 30, 539-546. 
Lechevalier, M. P. \& Lechevalier, H. A. (1970). Chemical composition as a criterion in the classification of aerobic actinomycetes. Int J Syst Bacteriol 20, 435-443.

Mesbah, M., Premachandran, U. \& Whitman, W. B. (1989). Precise measurement of the $\mathrm{G}+\mathrm{C}$ content of deoxyribonucleic acid by high-performance liquid chromatography. Int $J$ Syst Bacteriol 39, 159-167.

Mikami, H. \& Ishida, Y. (1983). Post-column fluorometric detection of reducing sugars in high-performance liquid chromatography using arginine. Bunseki Kagaku 32, E207-E210.

Minnikin, D. E., Alshamaony, L. \& Goodfellow, M. (1975). Differentiation of Mycobacterium, Nocardia and related taxa by thin-layer chromatographic analysis of whole-organism methanolysates. J Gen Microbiol 88, 200-206.

Minnikin, D. E., Collins, M. D. \& Goodfellow, M. (1979). Fatty acid and polar lipid composition in the classification of Cellulomonas, Oerskovia and related taxa. J Appl Bacteriol 47, 87-95.

Pascual, C., Lawson, P. A., Farrow, J. A., Gimenez, M. N. \& Collins, M. D. (1995). Phylogenetic analysis of the genus Corynebacterium based on $16 \mathrm{~S}$ rRNA gene sequences. Int $J$ Syst Bacteriol 45, 724-728.

Pitcher, D. G. (1983). Deoxyribonucleic acid base composition of Corynebacterium diphtheriae and other corynebacteria with cell wall type IV. FEMS Microbiol Lett 16, 291-295.

Pitcher, D., Soto, A., Soriano, F. \& Valero-Guillén, P. (1992). Classification of coryneform bacteria associated with human urinary tract infection (group D2) as Corynebacterium urealyticum sp. nov. Int J Syst Bacteriol 42, 178-181.

Riegel, P., de Briel, D., Prevost, G., Jehl, F. \& Monteil, H. (1993a). Proposal of Corynebacterium propinquum sp. nov. for Corynebacterium group ANF-3 strains. FEMS Microbiol Lett 113, 229-234.

Riegel, P., de Briel, D., Prévost, G., Jehl, F., Monteil, H. \& Minck, R. (1993b). Taxonomic study of Corynebacterium group ANF-1 strains: proposal of Corynebacterium afermentans sp. nov. containing the subspecies $C$. afermentans subsp. afermentans subsp. nov. and $C$. afermentans subsp. lipophilum subsp. nov. Int J Syst Bacteriol 43, 287-292.

Ruimy, R., Riegel, P., Boiron, P., Monteil, H. \& Christen, R. (1995). Phylogeny of the genus Corynebacterium deduced from analyses of small-subunit ribosomal DNA sequences. Int J Syst Bacteriol 45, 740-746.

Saito, H. \& Miura, K. (1963). Preparation of transforming deoxyribonucleic acid by phenol treatment. Biochim Biophys Acta 72, 619-629.

Saitou, N. \& Nei, M. (1987). The neighbor-joining method: a new method for reconstructing phylogenetic trees. Mol Biol Evol 4, 406-425.

Schleifer, K. H. \& Kandler, O. (1972). Peptidoglycan types of bacterial cell walls and their taxonomic implications. Bacteriol $\operatorname{Rev} 36,407-477$.

Suzuki, K. \& Komagata, K. (1983). Taxonomic significance of cellular fatty acid composition in some coryneform bacteria. Int $J$ Syst Bacteriol 33, 188-200.

Tamaoka, J. \& Komagata, K. (1984). Determination of DNA base composition by reversed-phase high performance liquid chromatography. FEMS Microbiol Lett 25, 125-128.

Uchida, K. \& Aida, K. (1977). Acyl type of bacterial cell wall: its simple identification by colorimetric method. J Gen Appl Microbiol 23, 249-260.

Willet, J. D., Sharpless, K. B., Lord, K. E., van Tamelen, E. E. \& Clayton, P. B. (1967). Squalene-2,3-oxide, and intermediate in enzymatic conversion of squalene to lanosterol and cholesterol. $J$ Biol Chem 242, 4182-4191.

Yamada, Y., Motoi, H., Kinoshita, S., Takada, N. \& Okada, H. (1975). Oxidative degradation of squalene by Arthrobacter species. Appl Microbiol 29, 400-404.

Yamada, Y., Kusuhara, N. \& Okada, H. (1977). Oxidation of linear terpenes and squalene variants by Arthrobacter sp. Appl Environ Microbiol 33, 771-776. 